communist period (Korini, 2012). The representative typology of the country corresponds to URM buildings. There are standard URM buildings all over the country for residential purposes, 5 stories with different plans. The majority of existing residential masonry buildings in Albania, like in many other European countries, has been designed considering earlier codes (KTP-9, 1978; KTP-N2, 1989) when seismic loads were not required or the design was to lower level of seismic loads of what is currently specified.

Masonry systems can be either engineered or nonengineered and be classified as unreinforced, confined and reinforced masonry. Each system has been built through different construction technologies and exhibit different earthquake responses; URM exhibits brittle failure whereas the other two have enhanced strength and ductility. This study aims to evaluate seismic capacity of the existing masonry residential buildings constructed per pre-modern seismic code (KTP-9, 1978) in Albania considering nonlinear behaviour of URM components. Three residential buildings with template designs constructed in accordance with Albanian Code (KTP-9, 1978) were selected to represent an important percentage of existing residential buildings in Albania of moderate seismicity. Selection of template designed buildings and material properties were based on field investigation, archive study and the blueprints of these structures. Mechanical characteristics for the case buildings were taken from their blueprints and adopted for the analysis. Capacity curves of investigated buildings were determined by pushover analyses conducted in two principal directions. Seismic capacity evaluation is carried out in accordance with FEMA (Federal Emergency Management Agency) 440 (FEMA 440, 2004). Reasons for building damages related to URM in past earthquakes are examined using the results of capacity assessment of investigated buildings. Deficiencies and possible solutions to improve the capacity of URM residential buildings are discussed.

\section{Description of structures}

Until the end of communist period in 1990s, masonry buildings continued to be built using template designs. Masonry was used for public and governmental buildings as a low cost construction method for that time. Today these buildings are still in use and the main functions are mostly for residential purposes. Hence, a considerable number of buildings have the same template designs in different parts of Albania (Korini, 2012).

A field and archive survey were carried out in Tirana city to select the most common template designs among residential buildings. Being the capital city of Albania, Tirana represents a medium-size city in a seismic part of Albania (Aliaj et al., 2010). According to survey results, there were about 30 types of residential buildings with template designs. It is observed that the most common templates are TD-83/3,

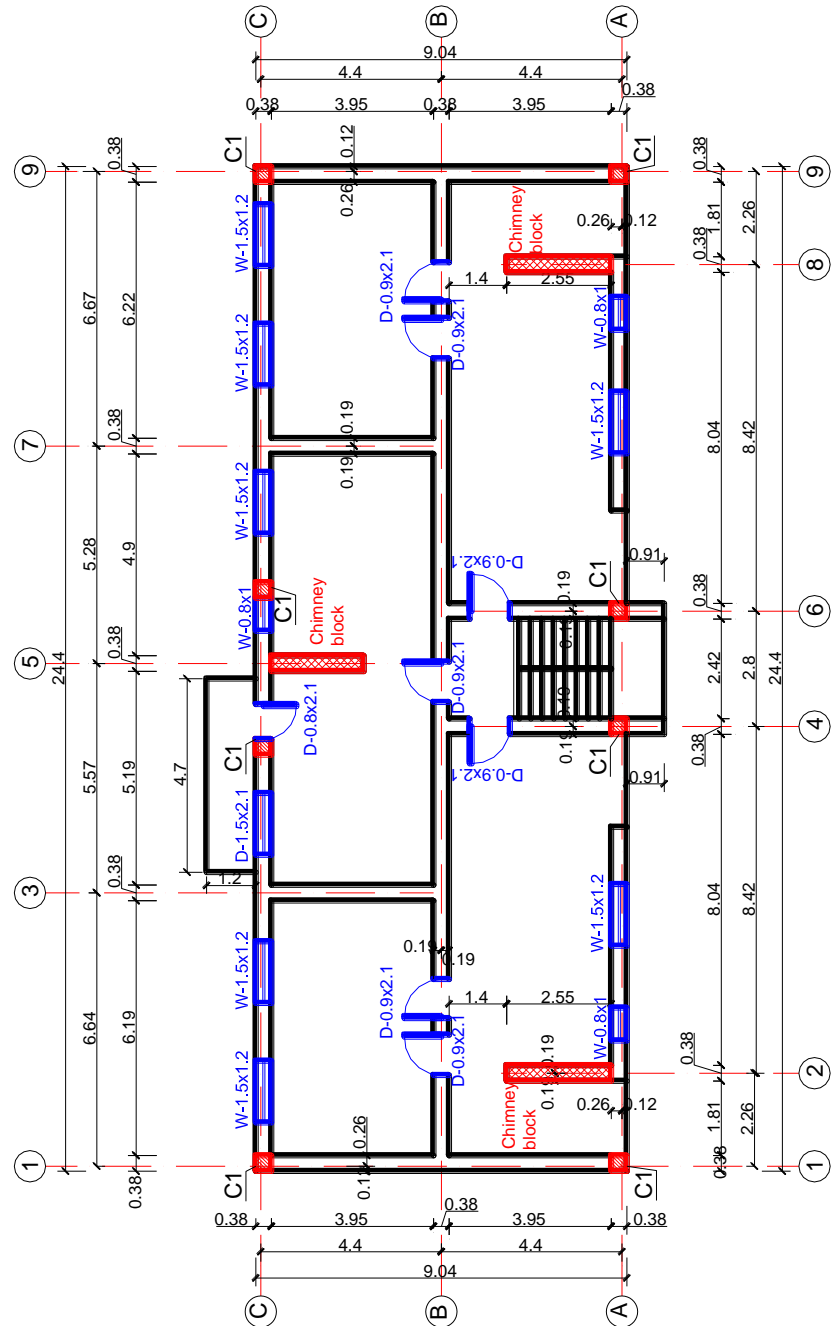

Fig. 1. Template design 83/3, (National Archive of Albania, 1983).

TD-72/3, and TD-72/1 which covers nearly $15 \%$ of the total building stock (Korini, 2012). According to the blueprints of each template design, selected buildings are built with clay bricks of M75 with a resistance of $7.5 \mathrm{MPa}$ and mortar of M25 with a resistance of $2.5 \mathrm{MPa}$. These mechanical properties taken from the blueprints of respective template designs are used and adopted for the analysis. Unlike many residential reinforced concrete buildings, URM buildings generally have a uniform distribution of mass and stiffness in horizontal and vertical plane because of similar architectural features due to similar purpose of use in all storeys. Therefore, they are less prone to structural irregularity effects such as, heavy overhangs, great eccentricities between mass and stiffness centres, etc. All of them have five floors. The load bearing wall thickness is $380 \mathrm{~mm}$ on first two storeys and $250 \mathrm{~mm}$ on the remaining three storeys. Representative plan views of the three buildings for the ground story are shown in Figs. 1-3. All dimensions are in $\mathrm{m}$. 


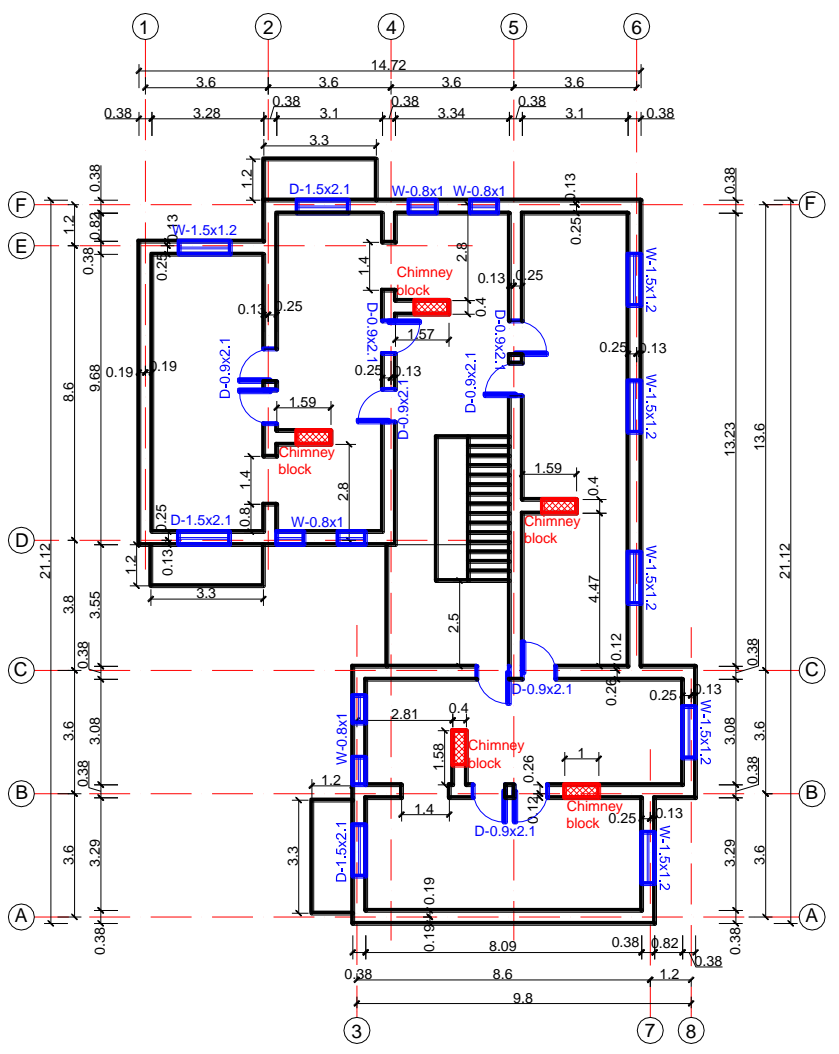

Fig. 2. Template design 72/3, (National Archive of Albania, 1983).

\section{Mathematical modelling of representative buildings}

SAP2000 (CSI, 2011) program has been used for modelling the considered building typologies. The 3-D modelling of URM buildings starts from the hypotheses on their structural and earthquake behaviour; the load bearing structure under horizontal and vertical loadings is defined, with walls and floors. The walls are the load bearing elements, while the floors are considered as planar stiffening elements (rigid diagrapham), on which the horizontal effects are distributed between the walls connected. Presence of ring beams in masonry prevents out-of-plane failure (Magenes, 2010) and provides the development of global structural behaviour governed by in-plane response of walls. This fact was also observed in previous shaking table tests (Benedetti et al., 1998; Mazzon et al., 2009). Experimental tests on masonry infilled concrete frames (Fardis, 1997) have revealed that severe acceleration levels are required to trigger an out-of-plane collapse due to increased natural period of vibration of the panel. In this study, the local flexural response of floors and out-of-plane behaviour of walls are not computed since they are considered as negligible with respect to the global building response dominated by their in-plane response.

For the modelling of the selected buildings two types of issues should be considered: correct representation of the mathematical model and inelastic characteristics of

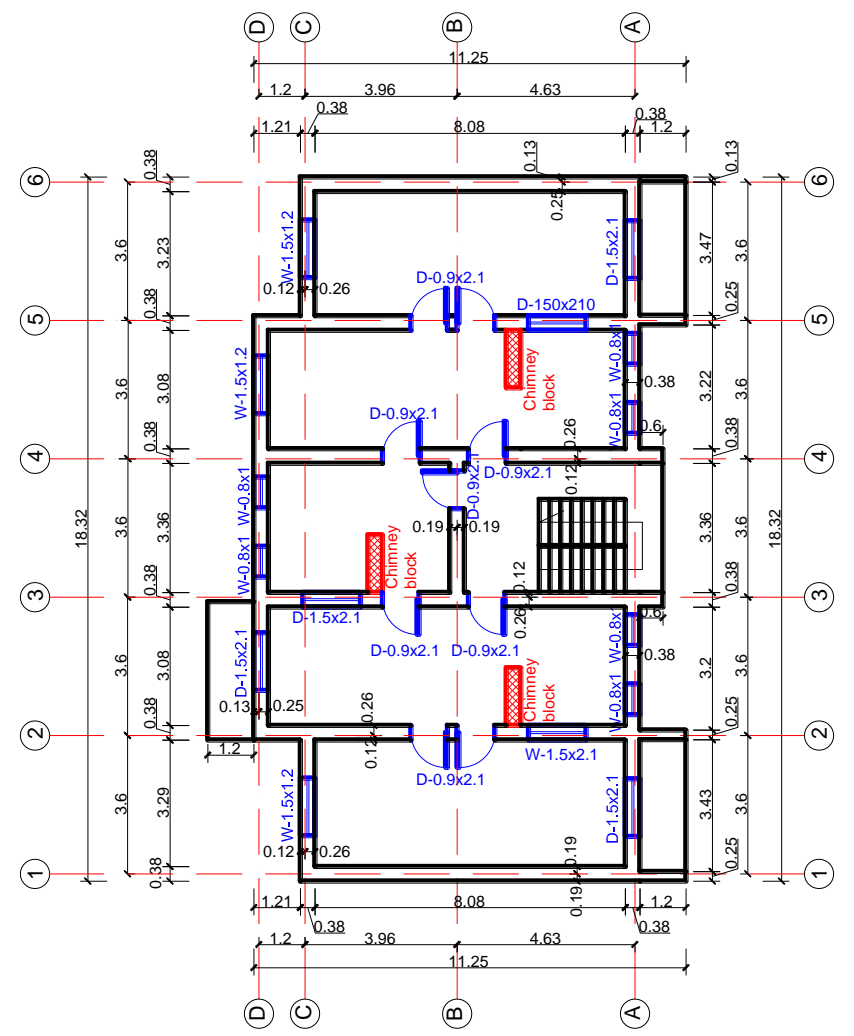

Fig. 3. Template design 72/1, (National Archive of Albania, 1983).

materials. URM is a composite construction material which consists of masonry units and mortar. Brick and stone are the usual elements of masonry units. Mortar is used to make the connection between these units. Under vertical and horizontal loads, load-bearing of masonry considered as the assemblage of the masonry units and mortar is influenced by the compressive, shear and flexural strengths, durability, water absorption and thermal expansion.

To model this anisotropy, two different approaches have been offered in literature: "micro modelling" and "macro modelling". Each modelling technique requires the adoption of different constitutive models. Modelling of masonry due to its anisotropic behaviour has been a very difficult task for several years. As a first approach, the finite elements methods can be used to model the masonry constitutive elements (mortar and unit elements). They are discretized into a certain number of finite elements then suitable constitutive nonlinear laws are adopted. A second approach is based upon the justification of "equivalent frames". The structure is described by an assemblage of piers and spandrel elements. These elements are connected by rigid offsets and modelled by proper constitutive laws in order to take into account the mechanical nonlinearity (Dolce, 1989). Several studies have been done by different researchers; (Lagomarsino et al., 2006; Gambarotta and Lagomarsino, 1997; Penelis, 2006; Calderini and Lagomarsino, 2008; Belmouden, 2009). In these approaches, 


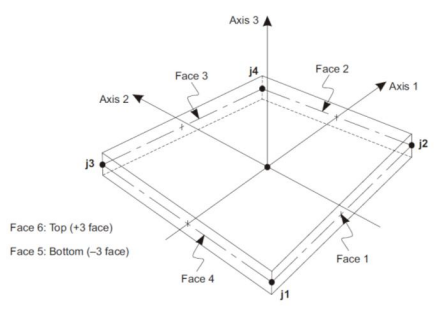

a) Four nodded shell element

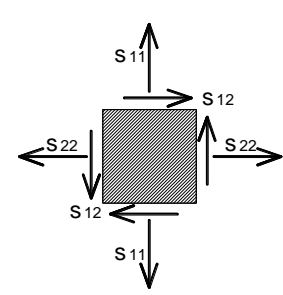

b) In-plane stresses

Fig. 4. A four nodded shell element and in plane stresses. (SAP2000 reference manual).

a nonlinear macro-element model, able to reproduce earthquake damage to masonry structures and failure modes observed during experimental testing, has been implemented with similar approximations.

For nonlinear analysis of the selected URM residential buildings, material properties determined from the blueprints of the designs were taken into account. As aforementioned, many of the buildings intended for residential services have similar construction procedure supervised by governmental authorities. Material properties considered in this study were determined based on an archive study of 30 buildings.

\section{Nonlinear material properties}

Pushover analyses have been performed using SAP2000 Nonlinear Version 15 (CSI, 2011) that is a general-purpose structural analysis program. Member sizes in the template designs were used to model the selected buildings for nonlinear analysis. No simplifications are made for members; like rounding-off or grouping members with close properties. All structural elements are modelled as given in the template design. Three-dimensional model of each building is created in SAP2000 to perform pushover analysis. Walls are modelled as nonlinear layered shell elements. The anisotropy of masonry is modelled by two different stress-strain curves. Each of them represents respectively vertical stresses S11, horizontal stress S22 and shear stress S12 (Fig. 4). S11 and S22 stress-strain curves are determined using the relation provided by Kaushik et al. (2007) (Fig. 5). Parabolic part of the curve is predicted by Eq. (1) which is valid until stress drops to $0.9 f_{\mathrm{m}}$ in the descending part.

$\begin{aligned} \frac{f_{\mathrm{m}}}{f_{\mathrm{m}}^{\prime}} & =2 \frac{\varepsilon_{\mathrm{m}}}{\varepsilon_{\mathrm{m}}^{\prime}}-\left(\frac{\varepsilon_{\mathrm{m}}}{\varepsilon_{\mathrm{m}}^{\prime}}\right)^{2} \\ f_{\mathrm{m}}^{\prime} & =0.63 \cdot f_{\mathrm{b}}^{0.49} f_{\mathrm{j}}^{0.32}\end{aligned}$

where $f_{\mathrm{m}}$ is the mortar compressive strength, $f_{\mathrm{m}}^{\prime}$ is the masonry compressive strength, $\varepsilon_{\mathrm{m}}$ is strain in masonry and $\varepsilon_{\mathrm{m}}^{\prime}$ is the peak strain corresponding to $f_{\mathrm{m}}^{\prime}$. In Eq. (2), $f_{\mathrm{b}}$ and $f_{\mathrm{j}}$; brick compressive strength according to Eurocode 6 (EN

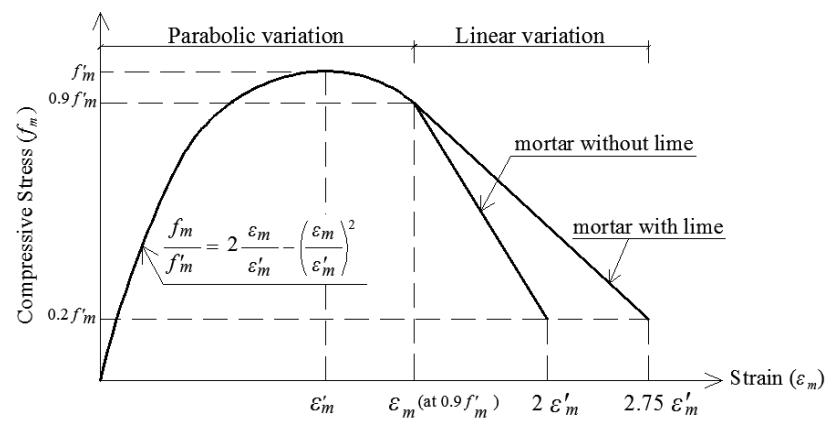

Fig. 5. Masonry idealised stress-strain curve for compression (Kaushik et al., 2007).

1996-1, 2005) and mortar compressive strength, respectively. Then a linear part is proposed for the curve. It is assumed that masonry may have a residual strength at $20 \%$, due to friction between detached parts. In this study, the Eq. (3) is used to estimate $\varepsilon_{\mathrm{m}}^{\prime}$.

$\varepsilon_{\mathrm{m}}^{\prime}=C_{\mathrm{j}}^{\prime} \times \frac{f_{\mathrm{m}}^{\prime}}{E_{\mathrm{m}}^{0.7}}$

$C_{\mathrm{j}}^{\prime}=\frac{0.27}{f_{\mathrm{j}}^{0.25}}$

On the other hand, to take into account the shear resistance, shear stress-strain curve should be defined. This curve needs to represent the horizontal failure. In reality, when a masonry member is subjected to lateral ground motion the horizontal resisting strength is represented by the cohesion and friction between brick and mortar which can be expressed with Coloumb friction (Eq. 5):

$\tau=c+\sigma \times \operatorname{tg} \varphi$

where $\sigma$ is the vertical stress and $\operatorname{tg} \varphi$ stands for friction between elements. In this study, shear resistance is represented by a material nonlinear curve (cohesion) and the friction is neglected. Annex C of EN 1998-3 (EC-8) provides drift limits for in-plane response of existing URM buildings. For the S12 stress-strain material curve, an approach which was used by researchers (Lagomarsino et al., 2006, 2007; Korini and Bilgin, 2012) have been taken into consideration and adopted for the analysis.

\section{Seismic demand}

Seismic loads are commonly represented by response spectrum functions which are derived from time history records of earthquakes in specific areas. Albania, located in the Balkan Peninsula, has a moderate seismic hazard and tectonic activity (Aliaj et al., 2010). Microzonation of the country allowed classifying the soil of the country in three types. 


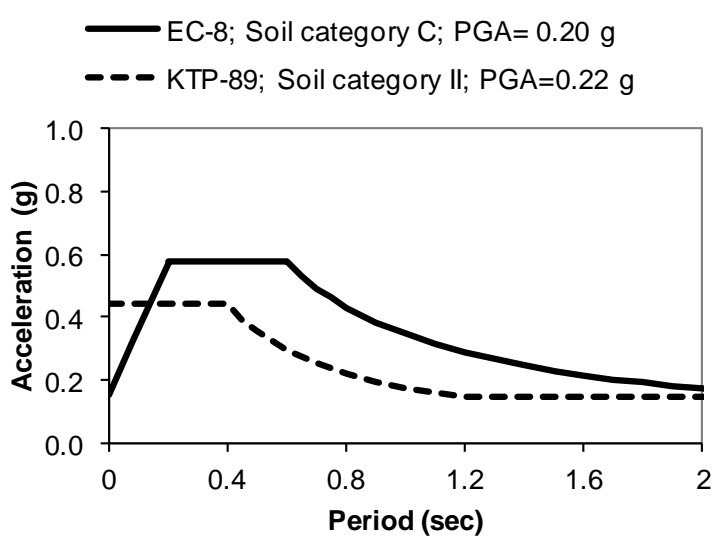

Fig. 6. Comparison of elastic response spectrums.

KTP-N2-89 normative design response spectrums are still used, since Eurocode 8 is not yet legally approved. In this study both Eurocode 8 and KTP-N2-89 spectrums are used in order to make a comparison and question the adequacy of current design spectrum. It is obvious that the Eurocode 8 spectrum has higher demand than the other (Fig. 6). Since the following existing structures have been constructed in different parts of the country, both ground conditions and seismicity is variable. In this study, the demand calculations for the seismic assessment of the considered buildings are performed considering the soil Type $\mathrm{C}$ with a moderate seismicity $(0.2 \mathrm{~g})$ according to Eurocode 8 (2004) and its corresponding spectra considering soil category II and medium seismicity (0.22 g) in KTP-N2-89 (1989).

\section{Identification of damage limit states}

A performance level is a limit state on the pushover curve that is used to classify the damage. As recommended by several researchers (e.g. Priestley, 1997), deformation thresholds may be the best indicators of identifying the limit states corresponding to structural and non-structural performance damage levels. In order to define these damage limits or performance levels of the URM template designs, there are neither experimental results based on laboratory tests nor available values calibrated from observed damages during the earthquakes. On the other hand, values of the mechanical properties of the materials used in these template designs have been taken from the blueprints of these projects and the actual values are not completely known. Considering all these aspects, there are different approaches to damage limit states classification for URM. Calvi (1999) and Lagomarsino and Penna (2003) have introduced different thresholds of the spectral displacement for discrete damage states based on the bilinear representation of the capacity spectrum. In this study for the performance assessment of the considered template designs, both thresholds have been employed.

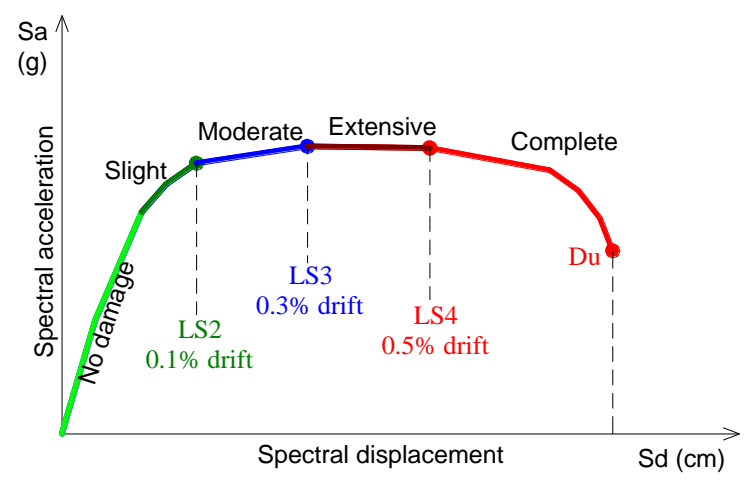

Fig. 7. Performance levels on pushover curve.

Calvi (1999) proposed four damage limit states for masonry structures (Fig. 7). Lagomarsino and Penna (2003) identified yield point and ultimate displacement for a structure and then split the capacity curve into 5 parts. Following the outlined criteria (see Tables 1 and 2); the thresholds of the spectral displacements are obtained for the damage limit states.

\section{Pushover analysis and capacity evaluation}

The pushover analysis consists of the application of gravity loads and a representative lateral load pattern. Gravity loads were in place during lateral loading. In all cases, lateral forces were applied monotonically in a step-by-step nonlinear static analysis. The applied lateral forces were proportional to the product of mass and the first mode shape amplitude at each story level under consideration.

In pushover analysis, the response of structure is characterised by a capacity curve that represents the relationship between the base shear force and the displacement of the roof. This useful demonstration is very practical and can easily be visualised by practising engineers. Roof displacement is commonly used for capacity curve.

Capacity evaluation of the investigated residential buildings is performed using damage limit states suggested by Calvi (1999). Pushover analysis data and criteria of Table 1 were used to determine inter-storey drift ratios of each building in both directions. Identification of damage limit states and its representations on capacity curves for each building is given in Figs. 8-10b and d. Small displacement capacities at different performance levels are remarkable for the buildings with greater openings in the respective directions due to failure of masonry elements. Also, TD- $83 / 3 \mathrm{x}$-direction and TD-72/3 in both directions do not have the expected displacement capacity due to lack of continuous walls (window openings) and irregularity in plans and elevations. The reductions in wall thickness cause a jump in inter-storey drift ratios at the third floor as obviously seen below (Figs. 8-10). 
Table 1. Performance levels and criteria provided by Calvi (1999).

\begin{tabular}{ll}
\hline Performance level & Performance criteria \\
\hline LS1 & - No damage \\
LS2 & - Structure can be utilised after the earthquake, without any need for significant \\
(Minor structural damage and/or moderate & strengthening and repair to structural elements. \\
non-structural damage) & - The suggested drift limit is $0.1 \%$. \\
LS3 & - The building cannot be used after the earthquake without significant repair. \\
(Significant structural damage and extensive & Still, repair and strengthening is feasible. \\
non-structural damage) & - The suggested drift limit is $0.3 \%$. \\
LS4 & - Repairing the building is neither possible nor economically reasonable. The \\
(Collapse) & structure will have to be demolished after the earthquake. Beyond this LS global \\
& collapse with danger for human life has to be expected. \\
& - The suggested drift limit is $0.5 \%$.
\end{tabular}

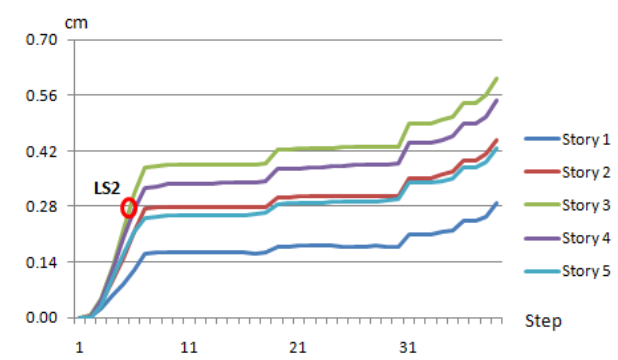

(a) Inter-storey drifts for $x$ - direction

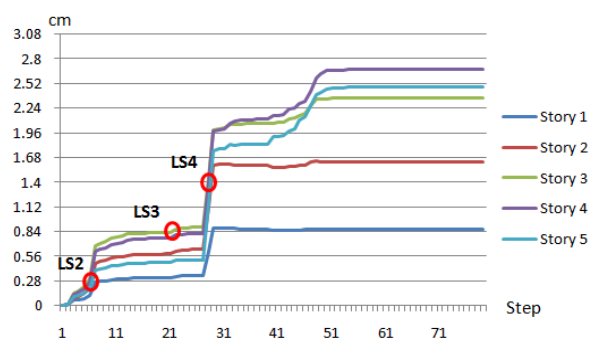

(c) Inter-storey drifts for y- direction

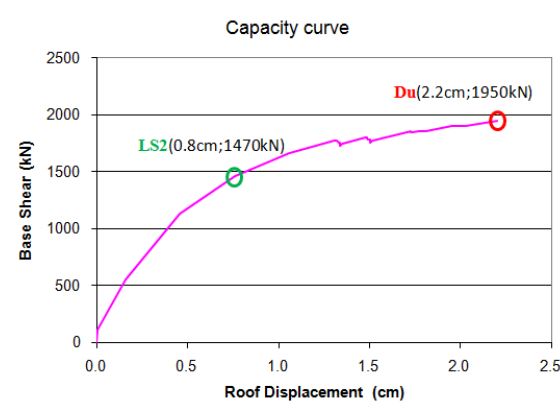

(b) Capacity curve in $x$ - direction

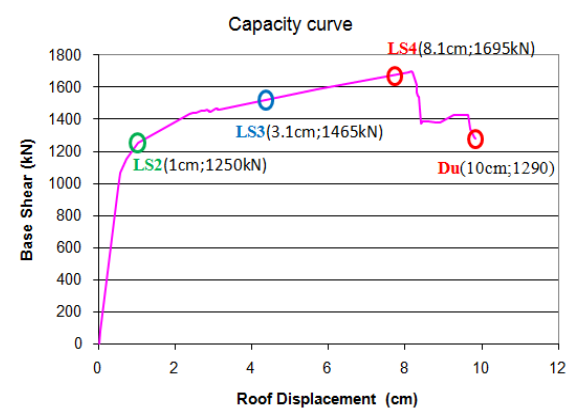

(d) Capacity curve in y- direction

Fig. 8. Inter-storey drift ratios and capacity curve representation of the TD-83/3 obtained by pushover analysis.

The accurate prediction of inter-storey drift ratio and its distribution along the height of the structures is very critical for the seismic performance evaluation purposes since the structural damage is directly related to this parameter. The inter-storey drift ratios and their corresponding profiles along the height of the template designs are illustrated in Figs. 8$10 \mathrm{a}$ and $\mathrm{c}$. As this is the case, the inter-storey drift ratio over the height of the structures become non-uniform as wall thickness changes.

Pushover analysis data and criteria of Table 2 were used to determine damage limit states according to Lagomarsino and Penna (2003) in both directions. Identification of damage limit states is given Table 3 .

The displacement capacity values are solely not meaningful themselves. They need to be compared with displacement 


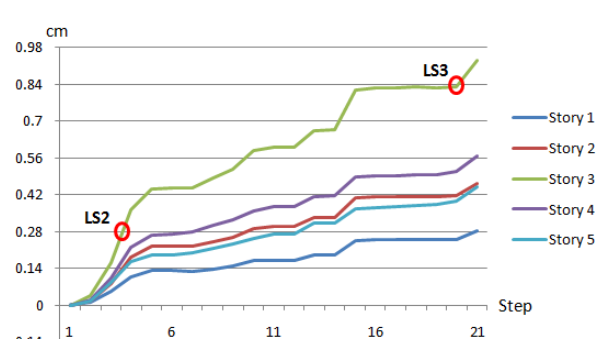

(a) Inter-storey drifts for $x$ - direction

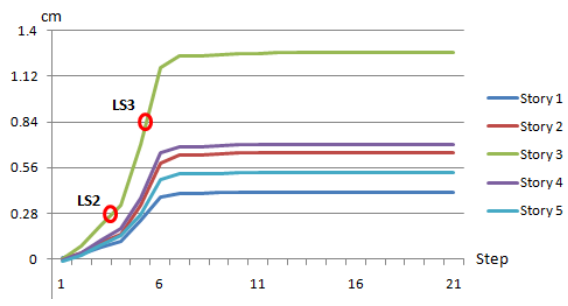

(c) Inter-storey drifts for $y$ - direction

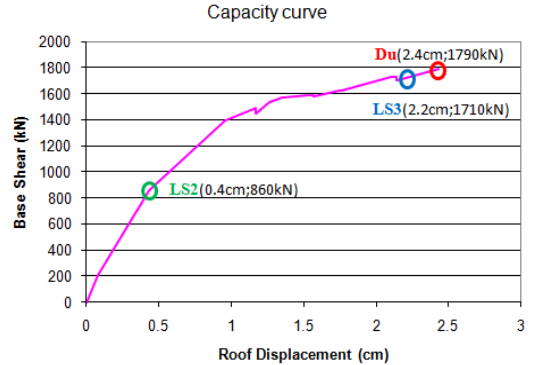

(b) Capacity curve in $x$ - direction

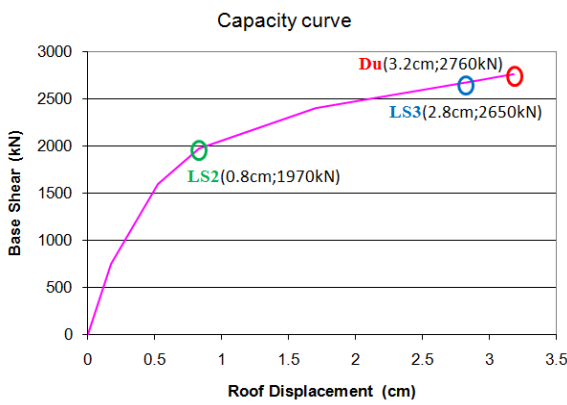

(d) Capacity curve in y-direction

Fig. 9. Inter-storey drift ratios and capacity curve representation of the TD-72/3 obtained by pushover analysis.

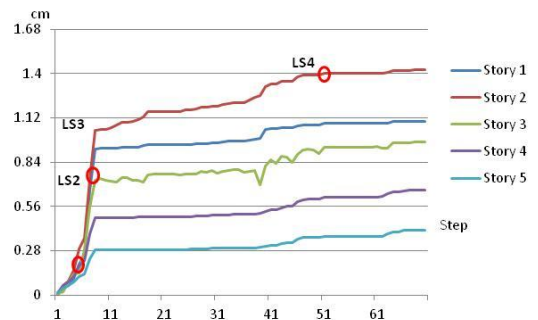

(a) Inter-storey drifts for $x$ - direction

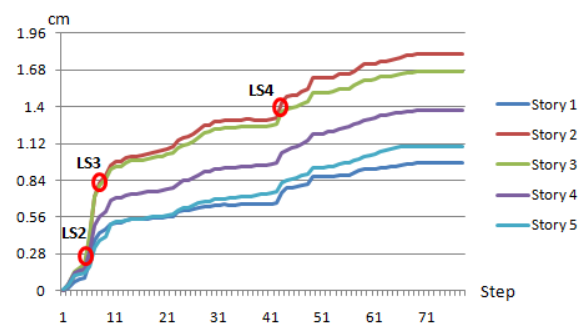

(c) Inter-storey drifts for y- direction

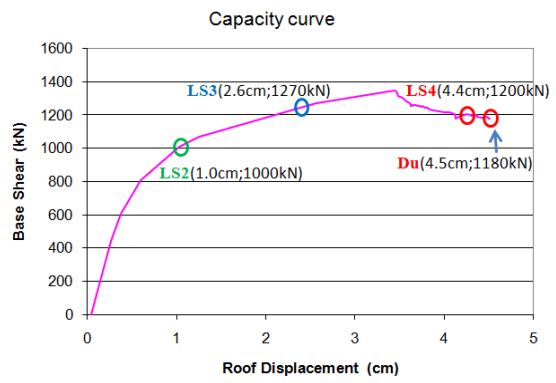

(b) Capacity curve in $x$ - direction

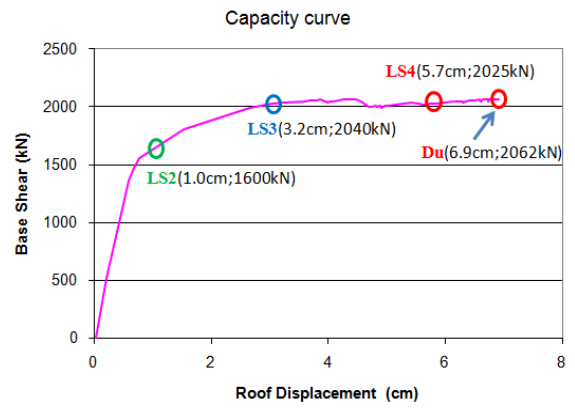

(d) Capacity curve in y- direction

Fig. 10. Inter-storey drift ratios and capacity curve representation of the TD-72/1 obtained by pushover analysis. 
Table 2. Performance levels and criteria provided by Lagomarsino and Penna (2003).

\begin{tabular}{ll}
\hline Damage state & Spectral displacement, $S_{\mathrm{d}}$ \\
\hline No damage & $S_{\mathrm{d}}<0.7 D_{\mathrm{y}}$ \\
Slight & $0.7 D_{\mathrm{y}}<S_{\mathrm{d}} \leq D_{\mathrm{y}}$ \\
Moderate & $D_{\mathrm{y}}<S_{\mathrm{d}} \leq D_{\mathrm{y}}+0.25\left(D_{\mathrm{u}}-D_{\mathrm{y}}\right)$ \\
Extensive & $D_{\mathrm{y}}+0.25\left(D_{\mathrm{u}}-D_{\mathrm{y}}\right)<S_{\mathrm{d}} \leq D_{\mathrm{u}}$ \\
Complete & $S_{\mathrm{d}}>D_{\mathrm{u}}$ \\
\hline
\end{tabular}

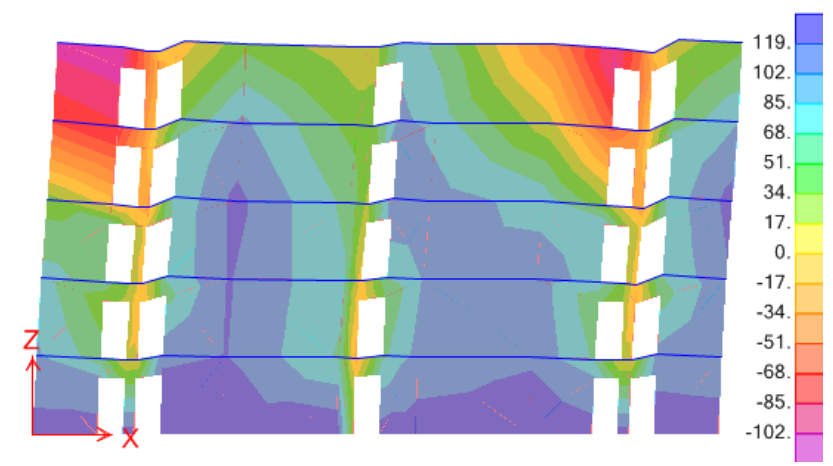

Fig. 11. Ultimate level of shear stress distribution for one wall element of TD-83/3 building obtained from pushover analysis ( $\mathrm{x}$ direction $-\mathrm{kPa}$ ).

demand values. According to modern codes, residential buildings are expected to satisfy a life safety performance level which corresponds to LS3 according to Calvi (1999) under design earthquakes, corresponding to $10 \%$ probability of exceedance in $50 \mathrm{yr}$ (Aliaj et al., 2010). Performance point estimates and damage limit states of building capacities corresponding to calculated performance levels are compared to see whether the residential buildings have adequate capacity. Performance points of the structures were obtained as described in FEMA 440. Table 4 lists performance levels of each building under both KTP-N2-89 and EC8 spectrum.

The seismic performance assessment is made for the three template design masonry buildings. For two of them the performance was insufficient and the risk of collapse was very high. Significant damage (LS3) is caused in all the obtained performances. The Albanian and European seismic codes produced different performance levels. European code was mostly unfavorable as expected. Only the third structure may be considered safe under the moderate seismic conditions taken into account. Performance assessment results are summarised in Table 5.

\section{Remarks on building responses}

TD-83/3 shows a brittle behaviour in $\mathrm{x}$-direction. This is probably because of the greater area of openings in this direction. Even though most of the masonry does not reach their
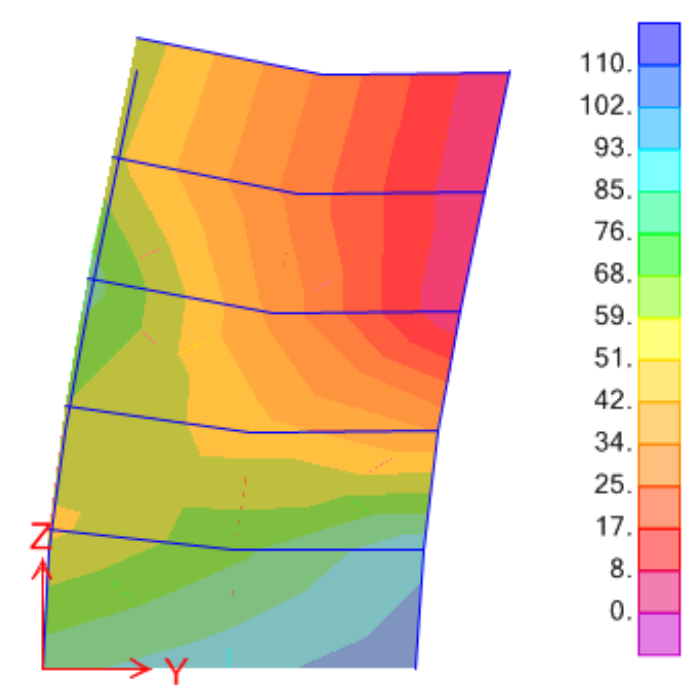

Fig. 12. Ultimate level of shear stress distribution for one pier element of TD-83/3 building obtained from pushover analysis (ydirection $-\mathrm{kPa}$ ).

ultimate shear capacity, some of the spandrel elements go failure (Fig. 11). The performance point is obtained by using FEMA 440 procedures only for KTP spectrum. Regarding Eurocode 8 spectrum, performance is not reached because of insufficient capacity in this direction. The y-direction behaviour is more ductile. Pier elements are more efficient (Fig. 12). The performance point is found under both spectrums (Table 4). The performance is lower than LS3 damage level for this direction and the damage is moderate in case of this type of earthquake happens.

TD-72/3 has a very brittle behaviour in the $\mathrm{x}$-direction. According to the pushover curve, it fails at the small range of displacements. Due to greater openings and plan irregularity, the performance point is obtained only for KTP-N2-89 spectrum with moderate damage (before LS3 level), but very close to collapse. The peripheral walls carry most of the load and they fail while most of the masonry does not reach ultimate shear resistance. Figure 13 shows a peripheral wall and another one with large openings at failure. The performance in $y$-direction is better than $\mathrm{x}$ - due to the efficiency of pier elements (Fig. 14). Performance point is found and LS3 level is satisfied only for KTP spectrum (Table 4). Although the response in y-direction is more ductile, it is not adequate to satisfy EC8 spectrum.

TD-72/1 shows a ductile behaviour in $\mathrm{x}$-direction. The regularity in plan and elevation makes a good distribution of stresses and increases energy dissipation capacity (Fig. 15). LS3 damage limit state is assured. Due to the low lateral load capacity, extensive damage is expected under EC8 spectrum. Performance point is reached only for EC8 spectrum and it is close to LS3 (Table 4). This building has a higher capacity and resistance in y-direction. Stresses are uniformly 
Table 3. Damage limit states according to Lagomarsino and Penna (2003).

\begin{tabular}{lrrrrr}
\hline \multirow{2}{*}{ Structure Type } & Direction & \multicolumn{4}{c}{ Damage Limit state thresholds (cm) } \\
\cline { 3 - 6 } & & Slight & Moderate & Extensive & Complete \\
\hline \multirow{2}{*}{ TD-83/3 } & X & 0.53 & 0.75 & 1.13 & 2.20 \\
& Y & 0.70 & 1.00 & 3.20 & 9.80 \\
TD-72/3 & X & 0.63 & 0.90 & 1.28 & 2.40 \\
& Y & 0.56 & 0.80 & 1.40 & 3.20 \\
TD-72/1 & X & 0.42 & 0.60 & 1.58 & 4.50 \\
& Y & 0.56 & 0.80 & 2.13 & 6.90 \\
\hline
\end{tabular}

Table 4. Performance points according to Fema 440 for the considered buildings under both spectrums.

\begin{tabular}{|c|c|c|c|c|c|c|c|}
\hline \multirow{3}{*}{ Design spectrum } & \multicolumn{5}{|c|}{ Performance points according to Fema 440} & & \\
\hline & \multirow{2}{*}{ Direction } & \multicolumn{2}{|c|}{ TD-83/3 } & \multicolumn{2}{|c|}{ TD-72/3 } & \multicolumn{2}{|c|}{ TD-72/1 } \\
\hline & & $\begin{array}{r}\text { Base shear } \\
(\mathrm{kN})\end{array}$ & $\begin{array}{r}\text { Displacement } \\
(\mathrm{cm})\end{array}$ & $\begin{array}{r}\text { Base shear } \\
(\mathrm{kN})\end{array}$ & $\begin{array}{r}\text { Displacement } \\
(\mathrm{cm})\end{array}$ & $\begin{array}{r}\text { Base shear } \\
(\mathrm{kN})\end{array}$ & $\begin{array}{r}\text { Displacement } \\
(\mathrm{cm})\end{array}$ \\
\hline \multirow{2}{*}{ Eurocode 8} & $\mathrm{x}$ & NA & NA & NA & NA & 1230 & 2.3 \\
\hline & $\mathrm{y}$ & 1430 & 2.4 & NA & NA & 1900 & 2.1 \\
\hline \multirow{2}{*}{ КТР-89 } & $\mathrm{x}$ & 1800 & 1.5 & 1630 & 1.8 & NA & NA \\
\hline & $\mathrm{y}$ & 1430 & 2.4 & 2410 & 1.7 & 1650 & 1.1 \\
\hline
\end{tabular}
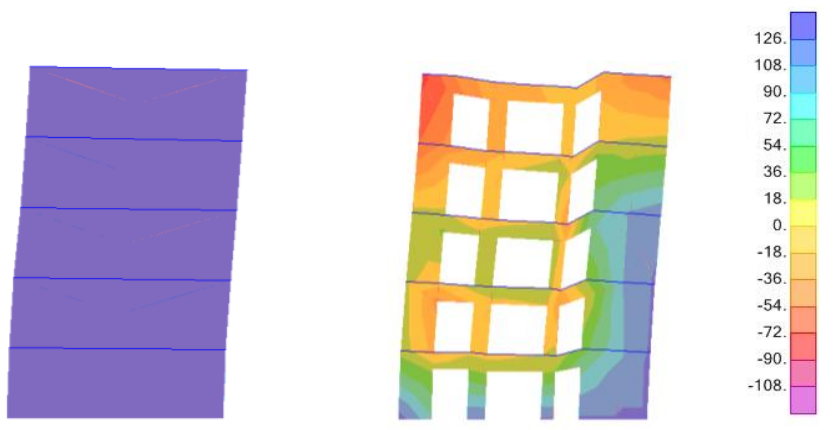

Fig. 13. Ultimate level of shear stress distribution for (a) a peripherial wall element; (b) one wall with opening of TD-72/3 building obtained from pushover analysis $(\mathrm{x}$-direction $-\mathrm{kPa}$ )

distributed (Fig. 16) and global response is satisfactory. Performance is found for both spectrums with a medium to high ductility (Table 3). LS3 damage level is satisfied for both spectrums. Moderate damage is caused by both of them, which is higher for EC8 seismic load. Also it is obvious the big distance between the performance point and ultimate LS4 damage level. This means that this structure is safe under both spectrums in y-direction.
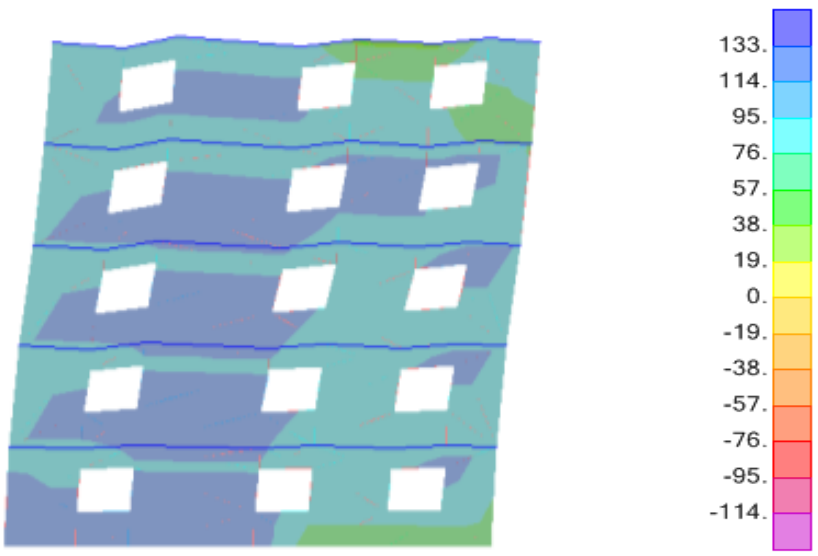

Fig. 14. Ultimate level of shear stress distribution for TD-72/3 building obtained from pushover analysis (y-direction $-\mathrm{kPa}$ ).

\section{Summary and conclusions}

This study evaluates seismic capacity of residential buildings with the selected template designs constructed per premodern code in Albania considering nonlinear behaviour of masonry. Three residential buildings with template designs were selected to represent an important percentage of residential building stock in mid-sized cities located in the seismic region of Albania. Selection of template designed buildings and material properties were based on field 
Table 5. Analysis results for all structure.

\begin{tabular}{|c|c|c|c|c|}
\hline Building ID & Direction & KTP-N2-89 Albanian & EC 8 & Comment \\
\hline \multirow{2}{*}{ TD-83/3 } & $\mathrm{x}$ & Safe LS3 & Risky* & Low stiffness according to Eurocode \\
\hline & $\mathrm{y}$ & Safe LS3 & Safe LS3 & Moderate damage under both spectrums \\
\hline \multirow{3}{*}{ TD-72/3 } & $\mathrm{x}$ & Safe LS3 & Risky* & Low stiffness according to \\
\hline & & & & Eurocode. Performance is close to collapse for KTP \\
\hline & $\mathrm{y}$ & Safe LS3 & Risky* & Low stiffness according to Eurocode but safe for KTP \\
\hline \multirow{2}{*}{ TD-72/1 } & $\mathrm{x}$ & Safe LS3 & Safe LS3 & Low stiffness according to KTP but safe for EC \\
\hline & $\mathrm{y}$ & Safe LS3 & Safe LS3 & Moderate damage under both spectrums \\
\hline
\end{tabular}

* Risky means no performance is found due to low stiffness.

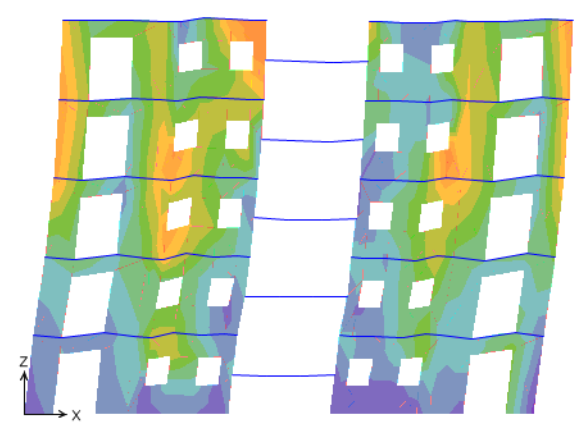

Fig. 15. Ultimate level of shear stress distribution of TD-72/1 building obtained from pushover analysis $(\mathrm{x}$-direction $-\mathrm{kPa})$.

investigation and survey in the governmental archives of Albania. Capacity curves of investigated buildings were determined by pushover analyses conducted in two principal directions. Seismic performance evaluation was carried out in accordance with Fema 440 provisions. Damage limit states thresholds suggested by Calvi (1999) and Lagomarsino and Penna (2003) have been used. Reasons of building damages in past earthquakes are examined using the results of capacity assessment of investigated buildings. Deficiencies and possible solutions to improve the capacity of residential buildings are discussed. The observations and findings of the current study are briefly summarised in the following:

1. Based on archive investigations according to the blueprints of each template design, selected buildings are built with clay bricks of M75 with a resistance of $7.5 \mathrm{MPa}$ and mortar of M25 with a resistance of $2.5 \mathrm{MPa}$.

2. Evaluation of the capacity curves for the investigated buildings points out that those storeys where the thicknesses of the walls are reduced may cause a deficiency in the seismic performance. Deformation demands are concentrated at the floor where the change occurs. Such abrupt changes in stiffness and strength may lead to failure at the level of change, since the load above and
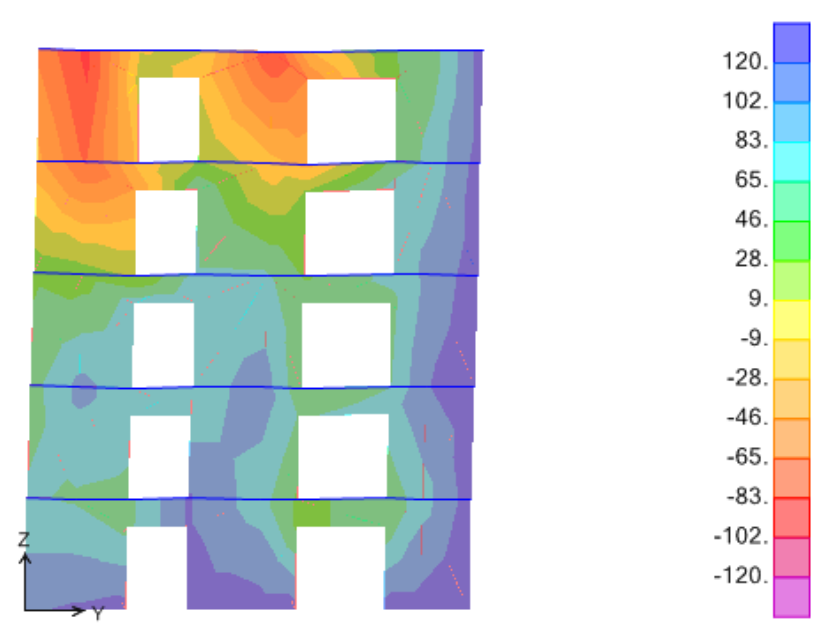

Fig. 16. Ultimate level of shear stress distribution of TD-72/1 building obtained from pushover analysis (y-direction $-\mathrm{kPa}$ ).

below the floor is similar. Observations on capacity curves considering the damage limit states thresholds generally being maximum in these stories (inter-storey drift ratios) shows this fact.

3. Regarding the stress distribution and inter-storey drift ratios, stress concentrations and inter-storey drifts are lumped at third story levels where a reduction from second storey to third storey was made. This type of sudden reduction in wall thickness cause deficiencies for the upper part of the building as it is observed in this study. Excessive inter-storey drift and inadequate shear strength may result in moderate to severe damage to these brittle structures. As a conclusion, wall thickness should be reduced in a gradual manner for new buildings.

4. Masonry shear walls are pierced by window and door openings. Above and below the opening, spandrels connect the walls. In direction where significant amount of openings, the capacity curves show the effects of discontinuity in masonry. The observations on the template designs indicated that although windows are located in 
both directions, openings are intensified in one orthogonal direction (longitudinal). Considering the fact that amount of openings is a significant parameter in the seismic performance of URM buildings, this situation can cause notable differences in lateral strength and displacement capacities in two orthogonal directions and clearly be observed from the capacity curves. Although the difference on lateral strength capacity is somewhat limited, the difference in displacement capacity is noteworthy. The displacement capacity in direction where the number of openings is intensified is less than half of that other. This study shows that the considered amount of openings decreases energy dissipation capacity by around $50 \%$ and therefore increases the sustained damage for this type of buildings. This might cause a deficiency in a probable future earthquake and preventive measures should be taken urgently.

5. The magnitude of maximum inter-storey drift ratios and the distribution of this ratio over the height of the all structures are very similar since the effects of higher modes are negligible and the response is primarily governed by the fundamental mode.

6. Recalling that these template structures were designed and constructed according to force based design approximations at the date of construction, such kind of deformation based deficiency (reduction of wall thickness and its effects on performance) may not be captured by means of force based evaluation procedures. On the other hand, performance based seismic assessment procedures are useful tools to correctly predict the deficiencies in this type of masonry constructions as in the case of framed structures.

7. In this study, two types of damage limits state definitions suggested by Calvi (1999) and Lagomarsino and Penna (2003) for the performance assessment of buildings have been taken into consideration. In the first approach, inter-storey drift ratios are used as damage limit states, whereas second one is useful if the assessment procedure is limited for global response prediction. For the studied buildings, while the second approach can give useful information for the global response of the buildings, it is incapable of representing the effects of change in wall thickness and its effects on seismic performance. Considering that all the template designs have wall thickness reduction from second to third story, first method seems more convenient for capturing such kind of deficiencies.

8. The observed building damages for URM structures during the past earthquakes support the analytical results obtained in this study; the reports and studies (Jagadish et al., 2003; Kaplan et al., 2010; Klingner, 2006; Tomazevic, 1999; Yoshimura and Kuroki, 2001) from past earthquakes pointed out masonry facades with numerous spandrels and between those spandrels failed due to shear. Stress concentrations due to shear in spandrels observed in pushover analyses for these constructions are clear indicators of such failures and potential risk in existing URM buildings for future earthquakes.

9. Shear failure of masonry piers seems the most frequent failure mechanism of URM buildings in the past earthquakes and the pushover analyses results support this fact. However, with regard to the ductility and energy dissipation capacity this mechanism is not favourable. Non-ductile behaviour of weak piers could be improved by means of adequately distributed bed joint reinforcements.

10. According to performance evaluation, template designs, except the TD 72/1 building, are far from satisfying the expected performance levels, suggesting that urgent planning and response need to be in action.

Acknowledgements. The authors would like to acknowledge the support provided by Epoka University. Appreciation is extended to reviewers for their invaluable positive contribution for the improvement of the paper.

Edited by: M. E. Contadakis

Reviewed by: N. Shkodrani and one anonymous referee

\section{References}

Aliaj, S., Koçiu, S., Muço, B., and Sulstarova, E.: Sizmiciteti sizmotektonika dhe vleresimi I rrezikut sizmik ne Shqiperi from the Academia e Shkencave e Shqipërisë, Academy of Sciences of Albania, Tirana, Albania, 2010.

Belmouden, Y. and Lestuzzi, P.: An equivalent frame model for seismic analysis of masonry and reinforced concrete buildings, Construct. Build. Material., 23, 40-53, 2009.

Benedetti, D., Carydis, G., and Pezzoli, P.: Shaking table tests on 24 simple masonry buildings, Earthq. Eng. Struct. Dynam., 27, 67-90, 1998.

Calderini, C. and Lagomarsino, S.: A continuum model for in-plane anisotropic inelastic behaviour of masonry, J. Struct. Eng., 134, 209-220, 2008.

Calvi, G. M.: A displacement-based approach for vulnerability evaluation of classes of buildings, J. Earthquake Eng., 3, 411-438, 1999.

CSI, SAP2000 V-15: Integrated finite element analysis and design of structures basic analysis reference manual, Berkeley, California (USA), Computers and Structures Inc, 2011.

Decanni, L., D’Amore, E., Goretti, A., Langenbach, R., Mollaioli, F., and Rasulo, A.: Performance of masonry buildings during the 2002 Molise, Italy earthquake, Earthq. Spectra, S1, 191-220, 2004. 
Dolce, M.: Models for in-plane loading of masonry walls, Course for the consolidation of masonry buildings in seismic zones, Ordine degli Ingegneri, Potenza, Italy, 1989.

EN 1996-1: European masonry design code, Design of masonry structures, Part 1: General rules for reinforced and unreinforced masonry structures, 2005.

EN 1998-1: European seismic design code, Design of structures for earthquake resistance, Part 1: General rules, seismic actions and rules for buildings, 2004.

Erberik, M. A. and Yakut, A.: Generation of fragility curves for Turkish masonry buildings considering in-plane failure modes, Earthq. Eng. Struct. Dynam., 37, 387-405, 2008.

Fardis, M. N.: Experimental and numerical investigations on the seismic response of RC infilled frames and recommendations for code provisions, Report no.6, PREC8, LNEC, Lisbon, 1997.

Federal Emergency Management Agency, Fema-440: Improvement of Nonlinear Static Seismic Analysis Procedures, Applied Technology Council, 2005.

Gambarotta, L. and Lagomarsino, S.: Damage models for the seismic response of brick masonry shear walls, Part II: the continuum model and its applications, Earthquake Eng. Struct. Dyn., 26, 441-463, 1997.

Gülhan, D. and Güney, Ö.: The behaviour of traditional building systems against earthquake and its comparison to reinforced concrete frame systems; experiences of Marmara earthquake damage assessment studies in Kocaeli and Sakarya, Earthquake-Safe International Conference on the Seismic Performance of Traditional Buildings, Istanbul, Turkey, available at: www.icomos.org/ iiwc/seismic/Gulhan.pdf, 2000.

Jagadish, K. S., Raguhanath, S., and Nanjunda Rao, K. S.: Behavior of masonry structures during the Bhuj earthquake of January 2001, J. Earth Syst. Sci., 112, 431-440, 2003.

Jagadish, K. S., Raguhanath, S., and Nanjunda Rao, K. S.: Behavior of masonry structures during the Bhuj earthquake of January 2001, J. Earth Syst. Sci., 112, 431-440, 2003/

Kaplan, H., Bilgin, H., Yilmaz, S., Binici, H., and Öztas, A.: Structural damages of L'Aquila (Italy) earthquake, Nat. Hazards Earth Syst. Sci., 10, 499-507, doi:10.5194/nhess-10-499-2010, 2010.

Kaushik, H. B., Rai, D. C., and Jain, S. K.: Stress-Strain characteristics of clay brick masonry under uniaxial compression, J. Material. Civil Eng., 19, 728-739, 2007.

Klingner, R. E.: Behavior of masonry in the Northridge (US) and Tecomán-Colima (Mexico) earthquakes: Lessons learned, and changes in US design provisions, Construct. Build. Material., 20, 209-219, 2006.
Korini, O.: Seismic Assessment of Albanian Masonry Buildings Using Nonlinear Procedures, MSc thesis, Epoka University, Tirana, Albania, 150 pp., 2012.

KTP-9-78: Albanian masonry design code, 1978.

KTP-N2-89: Albanian seismic design code, 1989.

Lagomarsino, S. and Penna, A.: Guidelines for the implementation of the II level vulnerability methodology, WP4: Vulnerability assessment of current buildings. RISK-UE project: An advanced approach to earthquake risk scenarios with application to different European towns, 2003.

Lagomarsino, S., Penna, A., and Galasco, A.: TREMURI program: seismic analysis program for 3D masonry buildings, University of Geneoa, Genoa, 2006.

Lagomarsino, S., Galasco, A., and Penna, A.: Nonlinear macro element dynamic analysis of masonry buildings, in: Proceedings of the ECCOMAS thematic conference on computational methods in structural dynamics and earthquake engineering, Rethymno, Crete, 2007.

Magenes, G.: Earthquake resistant design of masonry structures: rules, backgrounds, latest findings, Keynote Speech, in: Proceedings of the 8th international masonry conference, Dresden, Germany, 2010.

Mazzon, N., Valluzzi, M. R., Aoki, T., Garbin, E., De Canio, G., Ranieri, N., and Modena, C.: Shaking table tests on two multileaf stone masonry buildings, in: Proceedings of the 11th Canadian Masonry symposium, Toronto, 2009.

Pasticier, L., Amadio, C., and Fragiacomo, M.: Nonlinear seismic analysis and vulnerability evaluation of a masonry building by means of the SAP200 v.10 Code, Earthq. Eng. Struct. Dynam., 37, 467-484, 2008.

Penelis, Gr. G.: An efficient approach for pushover analysis of unreinforced masonry structures, J. Earthq. Eng., 10, 359-379, 2006.

Priestly, M. J. N.: Displacement-based seismic assessment of reinforced concrete buildings, J. Earthq. Eng., 1, 157-192, 1997.

Tomazevic, M.: Earthquake-resistant design of masonry buildings, Series on Innovation in Structures and Construction, Vol. 1, Imperial College Press, London, 1999.

Yilmaz, S., Tama, Y. S., and Bilgin, H.: Seismic Performance Evaluation of unreinforced masonry school buildings in Turkey, J. Vibration Control, doi:10.1177/1077546312453190, in press, 2012.

Yoshimura, K. and Kuroki, M.: Damage to Masonry buildings caused by the El Salvador earthquake of January 13, 2001, J. Nat. Disaster Sci., 23, 53-63, 2001. 